\title{
Probable historical record of the Slender-billed Curlew (Numenius tenuirostris) in the Czech Republic on the Moravian-Silesian territory
}

Jiří J. Hudeček

Probable historical record of the Slender-billed Curlew (Numenius tenuirostris) in the Czech Republic on the Moravian-Silesian territory - Acta Mus. Siles. Sci. Natur., 66: 281-287, 2017.

\begin{abstract}
The Slender-billed Curlew (Numenius tenuirostris) is a worldwide endangered bird species on the brink of extintion. For the last time it nested in Siberia, Russia. It flew trought Europe regulary in the 19th century. Because its records are unrepeatable, each date has a high scientific value. This article describes the historical record probably of the Czech Republic, probably in north-eastern Moravia in the environment of Místek in Lachia, probably between the years 1884 and 1897. This record might come from the collection of J. Bednař from the school in Místek (now Frýdek-Místek). These indirect data are provable and it is not possible to agree with the conclusion of the Czech Faunistic Committee which considers the location and date as unknown.
\end{abstract}

Key words: Slender-billed Curlew, Numenius tenuirostris, probably Moravian-Silesian borders and Lachia, probably historical occurrence

\section{Introduction}

The Slender-billed Curlew, Numenius tenuirostris Vieillot, 1817, is a rare species in Europe, North Africa and in the middle East, described by L. J. P. Vieillot from Egypt. Its last nesting was found in the environments of Omsk in Siberia, Russia, in 1924 (Belik 1994; Cooper \& Adams 2005,; Cleeves \& Crockford 2008; Cleeves et al. 2008, Donald et al. 2013; Hirschfeld et al. 2013; Bird-Life International 2015; Gils et al. 2015). In western Siberia it was seen on July 7, 1996 (Bojko \& Nowak 1996). According to the isotope analysis of feathers of young birds from museum collections, the nestling span was set for steppes of Kazakhstan and southern Russia between $48^{\circ} \mathrm{N}$ and $58^{\circ} \mathrm{N}$ latitudes (Buchanan et al. 2017). Al the tum of the 20th and 21th centuries it was seen flying in Oman, Marocco and Greece, for the last time in Hungary in 2001 and in 2003 and 2004 at the Danube delta (Oláh \& Pigniczki 2010; Zhmud 2005). Crockford (2009) attracted attention to the importance of documentation and museum collections. There were more occurrences in the Czech Republic in the 19th century and at the turn of the 19th and 20th centuries than given in literature. It was also seen somewhere in Bohemia (Hudeček 2016) and in the environments of Česká Lípa in northern Bohemia (Novozámecký pond, coordinate: 503742 / 1432 71, Vondráček 2002: 106). The exclusion of an almost extinct species from the list of Czech birds is completely ill-planned (Kren 2000: 270, Vavŕík \& Czech Faunistic Committee 2015), and it even is not in accordance with the known knowledge about its occurrence in central Europe (see Glutz von Blotzheim et al. 1977: 292-297).

\section{Slender-billed Curlew in a school in Místek}

In one of the offices in 6 th Primary school in Místek, in Pionýrů Street 400 (now FrýdekMístek) was in June 1992 found, determined and gained one adult male of the Slender-billed Curlew and donated to the Silesian Museum in Opava (donator Jiří J. Hudeček, deed of gift). On March 3, 1993, it was registered with an incremental number Z 12/93, and inventory number 3647 (Anonymus 1984-2013; Beneš et al. 2005, Fig. 1). This specimen was originally tagged 
with a plastered label as Whimbrel, Numenius phaeopus (Linnaeus, 1758) and name "Curlew" (in German: "Brachvogel"), with a set numbers. Origin label to seal of damaged plate with latin name of the Whimbrel (Fig. 2). The archival inventory list of the school collections was unfortunately shredded in 1981 (Hudeček in Hudec et al. 1995: 116, Beneš in Motýl 2000; Hudeček et al. 2002; Hudec \& Št’astný 2005: 638).

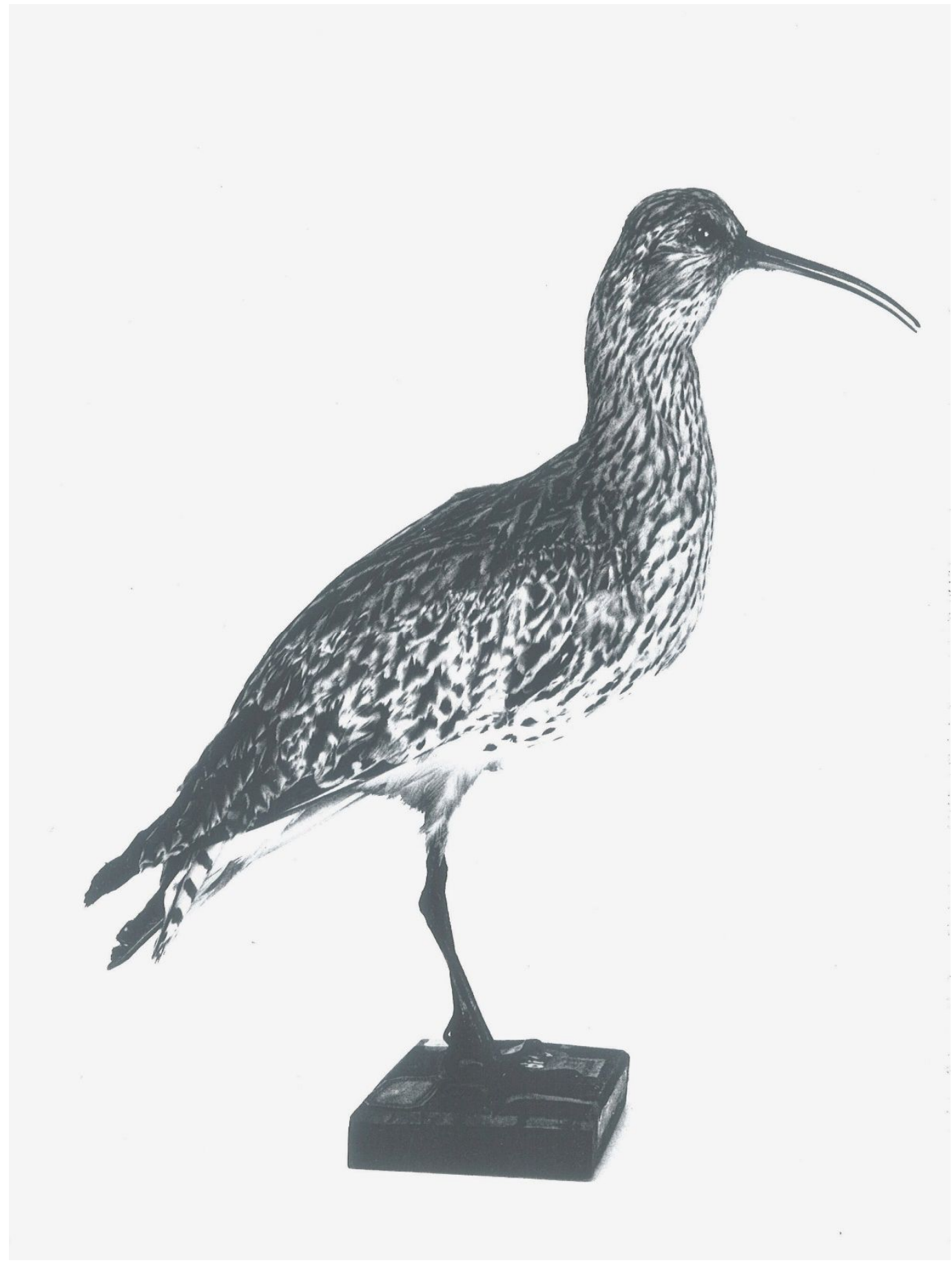

Fig 1: Slender-billed Curlew (Numenius tenuirostris), adult male, probably environment of Místek in Lachia, 19th century, collection Silesian Museum Opava, inventory number 3647. Photo Josef Solnický 


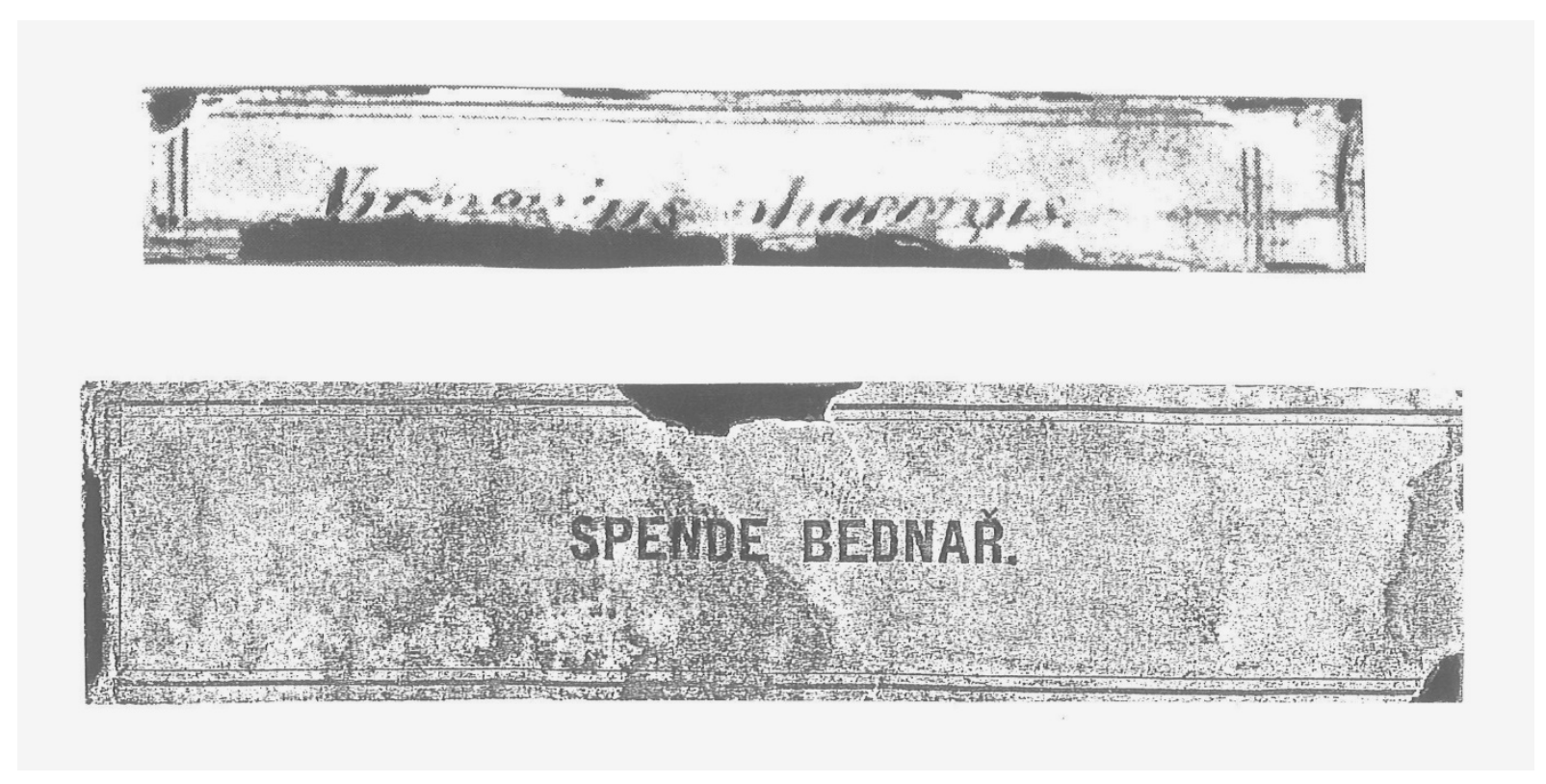

Fig 2: Comparsion of damagen label from the stand of Slender-billed Curlew (marked as Whimbrel), with specimen of label of collection Julius Bednař (in German "Spende Bednař" = donor Bednař)

\section{Origin from Lachia?}

A pharmacist and natural sciencist from Místek, Adolf Schwab (1807-1891), did not know anything about the occurrence of the Slender-billed Curlew and the Whimbrel in the environments of Místek (he gave some donations to Místek 'school in 1867, and he was literally active in 1879 for the last time, Schwab 1869; Hudeček \& Hanák 2000; von Wurzbach 1876; Anonymus 1891). Kadlčák (1905) wrote in his text "Fauna of the Beskydy territory in Lachia", and Linhart (1915) in text "Fauna of the Místek district" that the "Curlew" had been seen there. Also Jan Prášek (1874-?), a secondary school teacher in Místek and a natural scientist, wrote in his work "Ornithological situation in Lachia" that a "rainy Curlew(= the Whimbrel, Numenius phaeopus), the body lenght $50 \mathrm{~cm}$ was observed in Lachia" (Prášek 1908; Hudec et al. 1966, Fig. 3). From this can be logically deduced that the origin und time of record can probably be derived. The Czech name "koliha dešt'ová" = rainy Curlew is derived from the German name Regen Brachvogel and the name "Curlew" (German "Brachvogel", Czech "koliha") itself concerns the Whimbrel (Brehm 1830; Dalla-Torre \& Knauer 1887; for a detailed interpretation see Bertau 2014). Literature describes mistaking the Whimbrel and Slender-billed Curlew (Tschusi zu Schmidhoffen 1896). Lachia is an ethnographic area (Kolektiv 1993: 434; Krulikovský 2007) on the border between Moravia and Silesia, on both river banks of the Ostravice River so it can be concluded that the record happened somewhere in the environment of Místek. Probably it is a specimen from the collection of J. Bednař (Bednarz) and based on the period of his working in the local school, it might have been between the years 1884-1897. Julius Bednař (1856-1897) came from Červená Voda, graduated from a teachers institute in Brno, since 1884 he was the director of a German Utraquist town single-sex school for boys in Místek. Since 1894 he was a district inspector for townfolk schools. He died prematurely of a heart disease. Since 1886 he was a member of the Society for Natural Science in Brno (as very valuable member, Heinke 1890) where he was highly appreciated for his numerous gifts of birds and mammals. Thanks to Josef Talský he also became a member of the Ornithological Society in Vienna (Anonymus 1886). He wrote the obituary for A. Schwab (Bednař 1891). 
After Bednař's death, his zoological collection was donated to the town single-sex school for boys in Frýdek on February 23, 1897 (Anonymus 1897a; b; c; d). This school was also called "Below the owl", later on "School of Petr Bezruč", and was opened on December 2, 1888 (Hrozek 1965; Kulhánková 2014). A smaller part of the collections stayed in the town singlesex school for boys in Místek, whose last headquarters was the contenporary Primary School (renewed since September 1, 1961, in Pionýrů Street 400), where the described Slender-billed Curlew as Whimbrel was found. On October 17, 2013 in the Primary School in Místek, and on November 6, 2013 in collections and gained also the samples of his labels (Jiří J. Hudeček, Michal Jakubec). In his collection there were common bird and mammal species by writting the locations and dates directly on the base. Bednař's labels have identical features with the label on the Slender-billed Curlew (see Fig. 2).

$\mathrm{V}$ přeletu pozorovány některé druhy jespáki̊ (Tringa), zvláště yýše na severu. - Koliha veliká (Numenius arquatus) ${ }^{3}$ ) podobá se postavou cizokrajnému ibisu hnědému, zbarvenim skřivanu. Délka 58 až $70 \mathrm{~cm}$. Přilétá k nám zř́dka zê severu, zdržuje se na lukách, polích i úhorech, je plachá a nedá se snadno uloviti. Táhne-li v noci, slyšeti jeji hlasité volání „kuli“ vysoko ve vzduchu. ${ }^{4}$ ) - Břehouš (Limosa rufa) jen tehdy pezorován, když po velikých deštích se bažiny naplni; jinak vzácný. Zobák šedý, narudlý, oko tmavohnědé (obočí bilé), nohy černé. Na hlavě a na krku peři rezavohnědé, na hřbetě černohnědé se skvrnami rezavorudými, nad ocasem bilé se skvrnami hnědými, vespod všude rezavorudé s černými čárkami po stranách. Kryci pérạ křidel popelavá s ovrubami bílými a skvrnami rezavorudými, letky na vnějši pápěři až černé, na vnitřni hnědé se světlejšimi i

1) Na rybnicich zarostlỵch travou hol Olešné.

7) V horách pozorován na podzim na tahu chřástal neimenši (Porzana pygmaea).

3) Sa tahu strelena.

4) Také pozorována kolihá malá, vulg. deštová; délka těla až $50 \mathrm{~cm}$.

Fig 3: Observation of the Whimbrel (Numeniius phaeopus) at Lachia in environment of Místek (Prášek 1908: 22) At footnote number 4 is written: "Also observed of Whimbrel, people rainy Curlew, lenght of body as far as 50 $\mathrm{cm} "$.

\section{The Slender-billed Curlew and the Czech Faunistic Committee for Ornithology}

The record of the Slender-billed Curlew was given to the Czech Faunistic Committee for Ornithology, which registered it under a references number FK-H 06/2005 (Vavř́k in litt.). Without having properly taken into account all known related circumstances, they have concluded the matter under number FK 12/2014 as "rejected" and said it was the only evidence 
in our territory and that is why we cannot exclude or confirm the local origin: "the date and location are unknown". It is necessary to attract attention to a different approach to same questions (Anonymus s. d., b; here coloured photograph). Czech Faunistic Committee for Ornithology atributed the location and deduced date to the Northern Fulmar, Fulmarus glacialis (Linnaeus, 1761) found in a school in Písek (in Bohemia) based on the record of Alfred Horrice. And that all only evidence to the origin of the Northern Fulmar but the Czech Faunistic Committee for Ornithology, which does not approve of similar cases, approved of this highly probable record (Anonymus s. d., a). Unlike this, the found specimen of the Slender-billed Curlew has several indirect indications which might be used to state probable circumstances of the record: literary references, the location of the specimen in the school collection in Místek, the label and heading "Curlew" and "Whimbrel", according to its label coming from J. Bednař 's collection in the same school, a more accurate date of the specimen. This all increases the scientific, cultural, and museum value of the found specimen, in the 19th century, people knew about a regular migration of Slender-billed Curlew in Europe and their flying toward Místek might not have been impossible.

\section{Conclusions}

Kadlčák (1905) and Linhart (1915) recordes "the Curlew", Prášek (1908) "the Whimbrel" (= rainy Curlew) in Lachia, in environment of town Místek. In a school in Místek was found a Slender-billed Curlew, originally labelled as a Whimbrel. From this can be deduced the location of occurrence of an adult male bird, probably in the Czech Republic, in north-eastern Moravia in the ethnographic region of Lachia, probably somewhere in the vicinity of Místek (coordinate: $50412 / 142548$ ), probably in the years 1884-1897, probably from the collections of J. Bednar from the same school and according to the working period of this collector and his labels. The specimen is deposited in the Silesian Museum in Opava under an inventory number 3647. These indirect factś are sufficiently convincing. The record is registered by the Czech Faunistic Committee for Ornithology under number FK 12/2014, as rejected. Nevertheless, it cannot be agreed with their rejection and conclusions saying that the location and date are not known as vell as with their crossing out this species from Czech birds ist.

Acknowledgement: We thank for help to Marie Indráková, Alena Matějová, Miloš Glomb, Michal Jakubec, Libor Praus, Lukáš Synek and Kateřina Špačková.

\section{References}

An onymus (1886): Vereinsangellegenheiten. Neu beigetretene Mitglieder. - Mitt. Orn. Ver. Wien 10(11): 131.

- (1891): Úmrtí (A. Schwab). - Opav. Týdenník 22(2/1433): 3.

- (1897a): Bezirkschulinspector Bednarz. - Ostrauer Zeitung 16: 4.

- (1897b): Korespondenzen: Spende. - Ostrauer Zeitung 24: 2.

- (1897c): Úmrtí (J. Bednař). - Opav. Týdenník 28(12/2063): 3.

- (1897d): Z Mor. Ostravy: Úmrtí (J. Bednař). - Noviny Těšínské 3(10): 3.

- (s. d., a): Faunistická komise ČSO. Seznam pozorování, Downloaded from: http://fkcso.cz/fk/posuzovane.html

- (s. d., b): Pozorování, zaslaná k posouzení v roce 2014. Downloaded from: http://fkcso/aktuality/files2014.html

- (1984-2013): Slezské museum Opava, zoologické pracoviště. ms. Kniha př́růstků Z.

Bednař J. (1891): Adolf Schwab. Eine biographische Skizze. - Verh. Natur. Ver. Brünn 29: 268-269.

Belik V.P. (1994): Where on earth does the Slender-billed Curlew breed? - Wader Study Group Bull. 75: 37-38.

Beneš B., Hanák F. \& Hudeček J.J. (2005): Birds of Czech and Slovak Republics in Silesian museum Opava. - Zprávy MOS 63: 143-206.

Bertau P. (2014): Die Bedeutung historischer Vogelnamen. Nichtsingvögel. Band 1. Springer Verlag, BerlinHeidelberg.

BirdLife International (2015): Slender-billed Curlew, Numenius tenuirostris. IUCN Red List for birds. Downloaded from: http://www.birdlife.org (presented: Februar 2, 2015). 
Brehm C.L. (1830): Veschluss der Uebersicht der deutschen Vögel. - Isis von Oken 21: 1268-1285.

Bojko G.W. \& Nowak E. (1996): Observation of a Slender-billed Curlew in west Siberia. - Wader Study Group Bull. 81: 79 .

Buchanan G., Bond A., Crockford N., Kamp J., Pearce-Higgins J. \& Hilton G. (2017): The potential breeding range of Slender-billed Curlew, Numenius tenuirostris, identified from stable-isotope analysis. - Bird Conservation International 2017: 1-10.

Cleeves T.N. \& Crockford N. (2008): The Slender-billed Curlew, Numenius tenuirostris: the greatest European birding challenge. - Orn. Anzeiger 47(23): 198-207.

Cleeves T., Crockford N. \& Köhler P. (2008): Die grösste feldornithologische Herausforderung: Die suche nach dem Dünnschnabelbrachvogel. - Falke 55: 419-428.

Cooper J.H. \& Adams M.P. (2005): Extinct and endangered bird collections: managing the risk. - Zool. Med. Leiden 79-3(11): 123-130.

Crockford N. (2009): Can you help find the Slender-billed Curlew? - Wader Study Group Bull. 116: 62-64.

Dalla-Torre K. von \& Knauer F. (1887): Handwörterbuch der Zoologie. Ferdinand Enke, Stuttgart.

Donald P., Collar N., Marsden S. \& Pain D.J. (2013): Facing Extinction. The World Rarest Birds and the Race to Save Them: 2nd Edition. T \& AD Poyser, London.

Gills J. van, Wiersma P. \& Sharpe C.J. (2015): Slender-billed Curlew (Numenius tenuirostris). In: del Hoyo J., Elliot A., Sargatal J., Christie D.A., de Juana E. [eds]: Handbook of the Birds of the World alive. Lynx Edicions, Barcelona.

Glutz von Blotzheim U.N., Bauer K. \& Bezzel E. (1977): Handbuch der Vögel Mitteleuropas. Band 7, Teil 2 (Charadriiformes). Akad. Verlagsgesselschaft, Wiesbaden.

Heinke G. (1890): Jahresversammlung am 21. December 1889. - Verh. Natur. Ver. Brünn 18: 43-46.

Hrozek A. (1965): Školství ve Frýdku-Místku před protektorátem. In: 700 let Frýdku-Místku: 189-204. Měst nár. výbor, Frýdek-Místek.

Hirschfeld E., Swash A. \& Stiel R. (2013): The World's Rarest Birds. Princeton Univ. Press, New Jersey.

Hudec K. \& Št'astný K. [eds] (2005): Fauna ČR, sv. 29. Ptáci-Aves. Díl II/2 (2., přeprac. a doplněné vyd.). Academia, Praha.

Hudec K., Chytil J., Št'astný K. \& Bejček V. (1995): Birds of the Czech Republic. - Sylvia 31(2): 97-149.

Hudec K., Kondělka D. \& Novotný I. (1966): Ptactvo Slezska. Slezské museum, Opava.

Hudeček J.J. (2016): Slender-billed Curlew (Numenius tenuirostris) in the Czech Republic territory: the historical occurrence of this species in Bohemia and its return on the checklist. - Acta Mus. Siles., Sci. Natur. 65: 71-73.

Hudeček J.J. \& Hanák F. (2000): Die Vögel aus Europa in der naturhistorischen Sammlung von Adolf Schwab. - Zprávy MOS 58: 125-138.

Hudeček J.J., Beneš B. \& Hanák F. (2002): Slender-billed Curlew (Numenius tenuirostris) in collections of museums in the Czech Republic. - Zprávy MOS 60: 73-82.

Kadlčák J.M. (1905): Zvířena beskydské oblasti na Lašsku. In: Schücker J., Prášek J., Kadlčák J.M. [eds]: Památník Matice Místecké, pp. 29-33. Nákl. Matice Místecké, Místek.

Kolektiv autorů (1993): Geografický místopisný slovník světa. Academia, Praha.

Kren J. (2000): Birds of the Czech Republic. Christopher Helm, London.

Krulikovský Z.V. (2007): Lašsko. Etnografický a kulturní region Moravy a Slezska. Markrabství Lašské, s. 1.

Kulhánková R. (2014): Dějiny školství ve Frýdku-Místku. Diplomová práce. Univerzita Palackého, Ped. fak., Katedra společ. věd, Olomouc.

Motýl I. (2000): Kolihu tenkozobou léta nikdo neviděl. - Mladá Fronta Dnes, Severní Morava a Slezsko, 11 (273): 7.

Oláh J. \& Pigniczki C. (2010): New Hungarian record of Slender-billed Curlew (Numenius tenuirostris) in the Kiskumság (Hungary). - Aquila 16-17: 49-53.

Prášek J. (1908): Ornithologické poměry na Lašsku. Třináctá výroč. zpráva c.k. vyššího gymnasia v Místku za školní rok 1907-1908, pp. 3-26. Nák1. Matice Místecké, Místek.

Schwab A. (1869): Vogel-Fauna von Mistek und dessen weiterer Umgebung. - Verh. Natur. Ver. Brünn 7: 3160.

Tschusi zu Schmidhoffen V. von (1896): Nicht Numenius phaeopus, sondern tenuirostris in Tirol erlegt. - O. Jb. 7(5): 241

Vavřík M. (in litt.): Dopis Jiřímu J. Hudečkovi ze dne 20.3.2006.

Vavřík M. \& Czech Faunistic Committee (2015): Checklist of birds of the Czech Republic, Downloaded from: http://fkcso.cz/cz-list.htm

Vondráček J. (2002): Ornithological survey of the Novozámecký rybník National Natur Reserve. In: Tur oň ová D. [ed.]: Národní přírodní rezervace Novozámecký rybník: přirodovědné průzkumy a péče o chráněné území (Biological survey and management). - Př́roda 20: 1-176. 
Wurzbach C. von (1876): Adolf Schwab. In: Biographisches Lexikon des Kaiserthums Oesterreich. 32. Bd: 261 262. Verlag der k. k. Hof-und Staatsdruckerei, Wien.

Zhmud M. (2005): Slender-billed Curlew: promising discovery in the Danube delta. - Wader Study Group Bull. 106: 51-54.

Author's address: Jiří J. Hudeček, Hraniční 151 \& 230, CZ-742 83 Klimkovice, Czech Republic.

E-mail: waldrapp@seznam.cz 